\title{
DAMPAK COVID-19 BAGI UMKM DI INDONESIA PADA ERA NEW NORMAL
}

\author{
${ }^{1 *}$ Dede Hertina, ${ }^{2}$ Susanto Hendiarto, ${ }^{3}$ John Henry Wijaya \\ Universitas Widyatama \\ Email : ${ }^{1}$ dede.hertina@,widyatama.ac.id
}

Manuskrip: Sept-2020; Ditinjau: Okt-2020; Diterima: Okt-2020; Online: Jan-2021; Diterbitkan: Jan-2021

\begin{abstract}
ABSTRAK
Dampak UMKM di masa Pandemi Covid 19 dan Strategi Menghadapi Era New Normal sangat berpengaruh sekali terhadap keberlangsungan UMKM di Indonesia khususnya UMKM binaan Kadin Jawa Barat yang berasal dari berbagai kota, diseluruh Jawa Barat. UMKM yang dijadikan sampel adalah sebanyak 22 mitra usaha binaan Kadin Jawa Barat yang sebagian besar atau sekitar 70 persennya wanita dan mitra lainnya laki-laki. Metode kegiatan yang digunakan pada artikel Pengabdian Kepada Masyarakat ini diharapkan dapat memberikan kemudahan kepada peserta UMKM binaan Kadin Jawa Barat. Kesimpulan menyatakan Strategi Menghadapi Era New Normal Kenali perubahan perilaku konsumen dan bertransformasi secara proaktif,perkuat strategi pemasaran digital untuk tetap terhubung dengan pelanggan Untuk menghadapi pandemi global dan situasi new normal saat ini, para pelaku bisnis harus mencari cara untuk tetap terhubung dengan para pelanggan, tetap optimis di tengah masa sulit.
\end{abstract}

\section{Kata Kunci : Masa Pandemi Covid 19 dan Strategi Menghadapi Era New Normal}

\section{PENDAHULUAN}

Perkembangan UMKM (Usaha Mikro, Kecil dan Menengah) selama 10 tahun terakhir telah mengalami perkembangan hingga 99.9\% dari total unit usaha yang ada di Indonesia yang tersebar di seluruh Indonesia dengan jumlah hingga 62.9 juta unit. Bidang usaha UMKM ini terdiri atas bidang perdagangan, pertanian, peternakan, kehutanan, perikanan, pertambangan, pengolahan, bangunan, komunikasi, hotel, restaurant dan jasa-jasa lainnya.UMKM sendiri dapat dikategorikan sebagai usaha yang dimiliki oleh perorangan ataupun badan usaha yang produktif yang memenuhi criteria sebagai usaha mikro.Perkembangan ini tidak terlepas dari semakin majunya pertumbuhan UMKM seperti pemanfaatan sarana teknologi, informasi dan komunikasi, kemudahan peminjaman modal usaha, turunnya pajak PPH final.

Ditengah perkembangan UMKM yang semakin menjanjikan ini, pada awal tahun 2020 dunia diuji dengan pandemic Covid-19 yang dimulai di kota Wuhan, China. Untuk mencegah penyebaran virus Covid-19, pemerintah menarapkan 
kebijakan social distancing (pembatasan jarak social) dan berupaya untuk melakukan lockdown (karantina wilayah).Akibat dari kebijakan pemerintah ini, terjadi penurunan yang sangat drastic di berbagai sektor di Indonesia.Penurunan ini diakibatkan oleh diliburkannya segala aktivitas masyarakat, mulai dari aktivitas pendidikan hingga aktivitas perdagangan yang melibatkan kontak fisik dengan setiap pihak yang terlibat.Akibat bagi UMKM adalah terhambatnya kegiatan penjualan dan kegiatan produksi.Dalam menghadapi masa pandemi Covid-19, masyarakat harus selalu berhati-hati, menjaga jarak, memakai masker untuk mencegah dan menghentikan penyebarannya.Oleh karena besarnya dampak yang ditimbulkan oleh pandemic ini, maka dibutuhkan kesadaran dari seluruh elemen masyarakat untuk menyerahkan dan menuruti cara penanganan pandemi Covid-19 kepada pihak-pihak yang memiliki otoritas dan keahlian terkait seperti WHO, kementrian kesehatan, petugas kesehatan dan pemerintah yang dalam hal ini diwakili oleh Satgas Pencegahan Covid-19.

\section{Anakronisme Perspektif}

Salah satu faktor yang dapat memperluas penyebaran Covid-19 adalah anakronisme perspektif yang sudah teranjur beredar di masyarakat.Anakronisme perspektif adalah cara pandang yang dinilai kurang tepat dalam menghadapi penyebaran suatu pandemic, yang dalam hal ini adalah virus Covid-19.Akibatnya adalah upaya menghambat peluasan virus Covid-19 menjadi sulit.

Anakronisme perspektif yang paling terlihat jelas bagi kebiasaan dan kebudayaan di Indonesia, antara lain adalah:

1. Anakronisme sosial-budaya.

Masyarakat Indonesia merupakan masyarakat yang memiliki ikatan social yang tinggi, hal ini terlihat dari kegemaran akan berkumpul dalam suatu unit social yang saling berhubungan. Masyarakat Indonesia dikenal dengan kebiasaan gotong royong dan empati social. Ikatan ini sering diungkapkan memelalui sentuhan fisik seperti bersalaman, berpelukan,dan berbagai sentuhan fisik lainnya.

Sebagai upaya untuk mencegah penyebaran Covid-19 ini, maka kebiasaan ini harus ditinggalkan karena akan menimbulkan potensi penularan antara manusia dan manusia. Hambatan ini dapat menimbulkan gangguan socialbudaya yang berakibat pada diabaikannya protocol kesehatan yang telah diterapkan oleh pemerintah karena protocol kesehatan ini bertentangan dengan kebiasaan yang dijunjung tinggi oleh masyarakat Indonesia

2. Anakronisme konstruksi

Akibat dari pandemic Covid-19 ini, terjadi pembiasaan baru dalam seluruh kegiatan masyarakat, termasuk juga didalamnya pembiasaan baru dalam kegiatan keagamaan.Beragam platform social media terkadang mengakibatkan terjadinya informasi yang salah dan bahkan menyesatkan di tengah masyarakat.

Faktor-faktor yang membuat masih bertahannya UMKM di tengah pandemic Covid-19 adalah: 
1. UMKM yang dapat menghasilkan barang konsumsi dan jasa untuk kebutuhan dasar masyarakat.

2. UMKM memanfaatkan sumber daya manusia local, sumber daya bahan baku local dan peralatan local dan tidak mengandalkan impor

Upaya pemerintah untuk membantu UMKM adalah melakukan relokasi anggaran dan lebih memfokuskan pada kebijakan untuk memberikan insentif bagi UMKM dan pelaku usaha informal.Tujuannya adalah agar UMKM ini tetap dapat berproduksi dan tidak melakukan pemutusan hubungan kerja (PHK).Selain itu pemerintah juga berfokus pada bidang kesehatan yang diutamakan pada pengendalian penyebaran Covid-19; social safety net untuk bantuan-bantuan social yang diharapkan memberikan peningkatan konsumsi dan memperbesar Kredit Usaha Rakyat (KUR)..

\section{METODE PELAKSANAAN KEGIATAN}

Metode kegiatan yang digunakan pada artikel Pengabdian Kepada Masyarakat ini diharapkan dapat memberikan kemudahan kepada peserta kegiatan. Pelaku UMKM binaan Kadin Jawa Barat sebanyak 22 mitra binaan dari jenis yang berbeda ini sebagian besar atau 75 persennya adalah wanita dan mitra lainnya lakilaki. Dari keseluran mitra/pelaku UMKM, terdapat 9 pelaku UMKM yang memiliki usaha di bidang kuliner, 1 pelaku UMKM yang memiliki usaha di bidang herbal, 3 pelaku UMKM yang memiliki usaha di bidang kerajinan tangan, 1 pelaku UMKM yang memiliki usaha di bidang perlengkapan bayi, 3 pelaku UMKM yang memiliki usaha di bidang fashion sedangkan pelaku UMKM lainnya memiliki usaha di bidang kesehatan, fashion, 1 pelaku UMKM yang memiliki usaha di bidang alat musik, 2 pelaku UMKM yang memiliki usaha di bidang kosmetik dan produk kecantikan salon, 1 pelaku UMKM yang memiliki usaha di bidang industri dan satu lagi dibidang lainnya.

Dalam kegiatan ini, metode yang digunakan adalah penjelasan (pemaparan), diskusi dan tanya jawab melalui zoom webinar. Kegiatan melalui Zoom webinar dipilih untuk mendukung upaya pemerintah memutus rantai penyebaran virus corona (Covid-19) dengan melaksanakan physical distancing. Dengan bentuk kegiatan ini pihak perguruan tinggi tetap dapat produktif dan berbagi pengetahuan kepada masyarakat, terutama pelaku UMKM di Jawa Barat. Webinar ini mentargetkan para pelaku UMKM yang terkena dampak pandemi Covid-19, mampu melakukan penyesuaian akses layanan jual secara online dan tetap berupaya mempertahankan penjualan produk, sambil menggali informasi tentang kendala yang dihadapi pelaku UMKM pada masa pandemi Covid-19 dan memberikan kesempatan pada UMKM binaan Kadin Jawa Barat untuk menyampaikan harapan kepada pemerintah pusat dan pemerintah daerah dalam upaya bangkit setelah adanya pandemi Covid-19.

\section{HASIL DAN PEMBAHASAN}

Permasalahan yang dihadapi pelaku UMKM pada saat memasarkan produk dan jasa terutama pada masa Covid-19 adalah: (a) Masyarakat lebih memilih 
produk yang tingkat kebutuhannya lebih utama dibandingkan hanya membeli produk fashion, salon apalagi alat musik ; (b) Sulit mencari bahan baku; (c) Harga bahan baku mengalami kenaikan; (d) Konsumen lebih tertarik untuk produk kuliner seperti frozen food \& healthy food daripada produk craft dan fashion; (e) Masih terbatasnya kemampuan dalam melaksanakan pemasaran online; (f) Sebagian pelaku UMKM bekerjasama dengan mall, sehingga pemasaran terbatas ketika mall ditutup karena PSBB. Dalam pemasaran melalui media sosial, pelaku UMKM menghadapi permasalahan antara lain: (a) Sebagian pelaku UMKM belum mahir menggunakan sosial media dalam pemasaran; (b) Pelaku UMKM harus memiliki kuota yang memadai; (c) Persaingan semakin ketat; (d) Sebagia pelaku UMKM belum mengetahui cara menjangkau konsumen yang lebih luas dan tepat sasaran; (d) Konsumen mengeluhkan ongkos kirim; (e) Sebagian pelaku UMKM kesulitan menemukan ide atau gagasan dalam promosi produknya. Secara umum permasalahan yang dihadapi di pelaku UMKM binaan Kadin Jawa Barat, terkait dengan sertifikasi halal adalah: (a) Pelaku UMKM belum memahami tahapantahapan dalam memasarkan produk (b) Pelaku UMKM belum memahami alur proses untuk memasarkan produk melalui media sosial; (c) Sebagian pelaku UMKM memiliki dana yang terbatas untuk memperoleh modal.

Kegiatan pengabdian masyarakat yang telah kami laksanakan pada hari Rabu tangal 24 Juni 2020 untuk memberikan pengetahuan dan pemahaman mengenai dampak pandemi Covid-19 dan strategi menghadapi Era New normal bagi UMKM binaan Kadin Jawa Barat. Kegiatan ini didukung oleh Universitas Widyatama dan KADIN Jawa Barat.Pada Situasi Pandemi Covid-19" ini diharapkan dapat menjadi bagian dalam peran perguruan tinggi untuk mendukung pelaku UMKM di Jawa Barat untuk mampu bertahan dan tumbuh kembali di bidang usahanya. Melalui analisis kebutuhan yang telah dilakukan, tim pelaksana PKM mencoba mengajukan solusi terhadap permasalahan tersebut dengan menggunakan ilmu pengetahuan dan teknologi, yaitu melalui kegiatan: 1) Penyuluhan mengenai digital marketing melalui media sosial, 2). Pemahaman tentang pentingnya Pembuatan Laporan Keuangan

Secara umum permasalahan yang dihadapi di pelaku UMKM binaan Kadin Jawa Barat, terkait dengan sertifikasi halal adalah: (a) Pelaku UMKM belum memahami tahapan-tahapan dalam memasarkan produk (b) Pelaku UMKM belum memahami alur proses untuk memasarkan produk melalui media sosial; (c) Sebagian pelaku UMKM memiliki dana yang terbatas untuk memperoleh modal.Artikel ini diharapkan dapat memberikan pengetahuan dan pemahaman mengenai dampak pandemi Covid-19 bagi UMKM binaan Kadin Jawa Barat. Kegiatan ini didukung oleh Universitas Widyatama dan KADIN Jawa Barat Pada Situasi Pandemi Covid-19" ini diharapkan dapat menjadi bagian dalam peran perguruan tinggi untuk mendukung pelaku UMKM di Jawa Barat untuk mapu bertahan dan tumbuh kembali di bidang usahanya.Dengan memperhatikan permasalahan yang dihadapi pelaku UMKM binaan Kadin Jawa Barat, tim Pelaksana PKM memberi perhatian secara khusus pada penggunaan strategi pemasaran melalui media sosial dan peningkatan pemahaman pelaku UMKM. 
Berdasarkan pemasalahan tersebut, maka dianggap perlu untuk melakukan kegiatan pengabdian kepada masyarakat kepada pelaku UMKM Jawa Barat yang terkait dengan kedua permasalahan tersebut.Melalui analisis kebutuhan yang telah dilakukan, tim pelaksana PKM mencoba mengajukan solusi terhadap permasalahan tersebut dengan menggunakan ilmu pengetahuan dan teknologi.

Dampak Virus COVID-19 di Indonesia

Covid-19 ini sangat berdampak pada perekonomian di Indonesia, tidak hanya produksi barang saja yang terganggu, tetapi investasi di berbagai sektor pun juga terhambat.Berikut ini adalah beberapa dampak virus COVID-19 di Indonesia:

1. Beberapa barang menjadi mahal dan langka untuk ditemukan.

2. Jemaah Indonesia batal berangkat umrah.

3. Kunjungan para wisatawan mancanegara di Indonesia menurun.

4. Merusak tatanan ekonomi di Indonesia.

5. Impor barang menjadi terhambat.

Menurut Kementrian Koperasi, dampak pandemic Covid-19 telah mengubah tatanan hingga 37,000 pengusaha UMKM di seluruh Indonesia. Akibat dari pandemic ini adalah berubahnya pola konsumsi masyarakat, yang berakibat pada menurunya jumlah transaksi penjualan. Apabila sebelum pandemic Covid-19, konsumen menghabiskan dana mereka untuk produk-produk konsumtif dan produk non konsumtif, maka setelah terjadi pandemic Covid-19, konsumen beralih dengan tidak mengkonsumsi barang-barang yang bersifat konsumtif dan beralih ke barangbarang kebutuhan dasar. Produk kebutuhan dasar yang difokuskan oleh masyarakat adalah terutama untuk produk-produk pangan. Akibatnya adalah sektor-sektor yang menjual produknya di sektor non konsumtif mengalami penurunan transaksi sebesar $80-85 \%$ sejak terjadinya pandemic Covid-19 dan diberlakukannya PSBB. Walaupun konsumen beralih dengan berfokus pada produk-produk pangan, sektor inipun mengalami penurunan penjualan sebesar $30-40 \%$

Strategi UMKM dalam menghadapi era New Normal:

a. UMKM harus mengenali perubahan perilaku konsumen dan beradaptasi dengan perubahan tersebut. Pandemic Covid-19 telah mengubah secara drastic cara interaksi perusahaan dengan konsumennya.Oleh karena itu perusahaan harus beradaptasi terhadap perubahan perilaku tersebut. Salah satu cara yang dapat dilakukan adalah dengan memfokuskan pada transaksi secara online, hal ini dikarenakan perusahaan dan konsumen akan saling membatasi diri dalam berinteraksi secara fisik. Studi Nielsen menyebutkan bahwa terjadi peningkatan dalam transaksi berbelanja secara dan online dan bahkan konsumen masih akan terus bertransaksi secara online walaupun pandemic Covid-19 telah berakhir.

b. Memperkuat pemasaran digital untuk tetap terhubung dengan konsumen. Perusahaan harus mencari cara agar tetap terhubung dengan konsumennya, walaupun hanya melalui dunia maya di media social.Perusahaan dapat memanfaatkan social media untuk menawarkan produk baru, dan terus berhubungan dengan konsumennya melalui promosi-promosi yang menarik. 
c. Tetap berpikiran positif di tengah pandemic Covid-19. Menurut riset yang dilakukan oleh McKinsey, selama pandemic Covid-19 ini konsumen mengalami penurunan pendapatan yang signifikan, namun aktivitas konsumsi tetap berjalan seperti biasa. Yang berubah dari pola konsumsi ini hanyalah media yang digunakan. Apabila sebelum pandemic Covid-19 konsumen akan melakukan interaksi langsung dengan produsen, namun semenjak terjadi pandemic Covid19 pola interaksi konsumen berubah dari interaksi langsung menjadi interaksi tidak langsung. Hal ini sebenarnya merupakan sebuah peluang bagi UMKM untuk tetap bertahan dalam usahanya.

\section{KESIMPULAN DAN SARAN}

Berdasarkan penjelasan diatas, maka strategi UMKM dalam menghadapi era new normal adalah mengenali perubahan perilaku konsumen dan berubah seiring dengan perubahan perilaku tersebut; memperkuat strategi pemasaran digital dalam rangka aga selalu terhubung dengan konsumen; tetap memiliki pandangan yang optimis ditengah pandemic Covid-19.

\section{DAFTAR PUSTAKA}

Ajimat, A., Sunarsi, D., \& Sidiq, F. (2020). Berwirausaha Memanfaatkan Media Sosial Pada Daerah Sepatan. ADI Pengabdian Kepada Masyarakat, 1(1), 69-76.

Ananda Muhammad Firdaus, Masalah UMKM Tidak Hanya Terpaku di Modal, pada URL http://www.ayopurwakarta.com/read/2020/07/16/5517/masalahumkm-tidak-hanya-terpaku-di-modal,Republika.co.id

D, S., \& Preswari. (2011). strategi pengembangan industri kreatif untuk meningkatkan daya saing pelaku ekonomi lokal. jurnal aplikasi managemen, 9, 301-308.

Darwanto. (2013). peningkatan daya saing UMKM berbasis inovasi dan kreatifitas (strategi penguatan property right terhadap inovasi dan kreatifitas. jurnal bisnis dan ekonomi, 20, 142-149.

Effendy, A., \& Sunarsi, D. (2020). Persepsi Mahasiswa Terhadap Kemampuan Dalam Mendirikan UMKM Dan Efektivitas Promosi Melalui Online Di Kota Tangerang Selatan. Jurnal Ilmiah MEA (Manajemen, Ekonomi, \& Akuntansi), 4(3), 702-714. https://doi.org/10.31955/mea.vol4.iss3.pp702$\underline{714}$

Hamid, E. S., \& Susilo, Y. S. (2011). Strategi Pengembangan Usaha Mikro Kecil dan Menengah di Profinsi Daerah Istimewa Yogyakarta.

Haque, MG., Munawaroh, Sunarsi, D., (2020). Analysis of SMEs Culinary Marketing Strategy During Covid 19 Pancemic: A Study at "Sate Bebek Cilegon" Resto in Cilegon, Banten. International Journal of Education, Information Technology, and Others. Vol.3. Issue 2

Hutabarat, L., \& M, R. F. W. (2015). Strategi Pengembangan Usaha Kuliner di Kota Malang Berbasis Ekonomi Kreatif. 
Indonesia, D. p. r. (2008).cetak biru pengembangan ekonomi kreatif indonesia 2025. jakarta.

RI, M. P. d. K. (2014). Paparan Wakil Menteri Pendidikan dan Kebudayaan RI Bidang Pendidikan Retrieved 23 Januari, 2018, from https://kemdikbud.go.id/kemdikbud/dokumen/Paparan/Paparan\%20Wame ndik.pdf

Ritzer, George dan Douglas J. Goodman, Teori Sosiologi Modern, Jakarta: Prenada Media, 2004

Ritzer, George, Sosiologi Ilmu Pengetahuan Berparadigma Ganda, Jakarta: PT. Raja Grafindo Persada, 2010

Sunarsi, D. (2020). Implikasi Digitalisasi Umkm. Digitalisasi UMKM, 57. books.google.com

Wahyudi, S. (2012).usaha pengembangan industri kreatif desa.

West, Ricard \& Lynn H. Turner. 2012. Pengantar Teori Komunikasi Analisis dan Aplikasi. Terjemahan dari Introducing Communication Theory: Analysis and Application. Jakarta: Salemba Humanika 